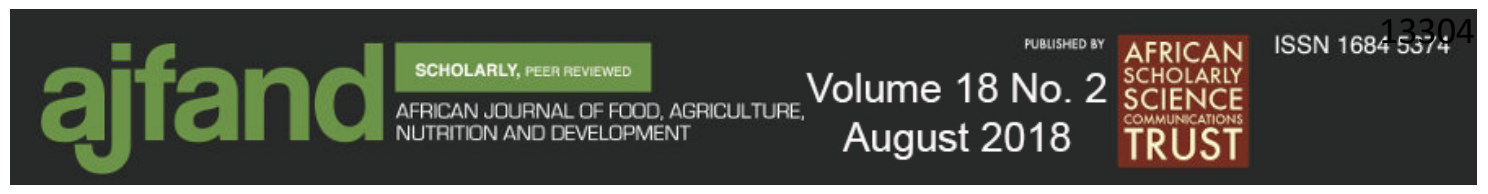

Afr. J. Food Agric. Nutr. Dev. 2018; 18(2): 13304-13316

DOI: 10.18697/ajfand.82.16685

\title{
AGRONOMIC PERFORMANCE OF FOUR UPLAND RICE GENOTYPES UNDER RAINFED CONDITION
}

Ndebeh AK ${ }^{1}$, Asumanah $P^{2}$, Ndebeh $\mathbf{J}^{1 \& 5}$, Ndaloma PG ${ }^{1}$, Lahai SJB ${ }^{1}$, Kolleh $\mathrm{DM}^{3}$ and JK Ahiakpa ${ }^{1 \& 4^{*}}$

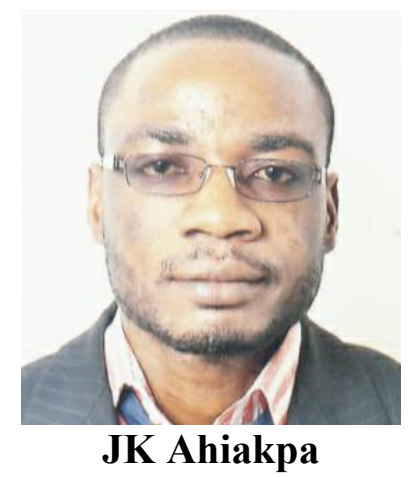

*Correspondence email: jnckay@gmail.com

${ }^{1}$ Department of Plant and Soil Sciences, College of Agriculture and Sustainable Development, Cuttington University, Suakoko, Bong County, Liberia

${ }^{2}$ Department of Animal Science and Health, College of Agriculture and Sustainable Development, Cuttington University, Suakoko, Bong County, Liberia

${ }^{3}$ Department of Natural Resources Management, College of Agriculture and Sustainable Development, Cuttington University, Suakoko, Bong County, Liberia

${ }^{4}$ Research Desk Consulting Ltd., Kwabenya-Accra, Ghana

${ }^{5}$ Rice Production Department, Central Agriculture Research Institute, Suakoko, Bong County, Liberia 


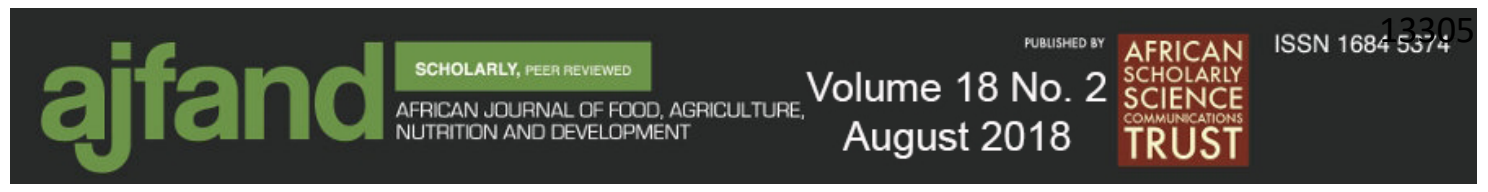

\begin{abstract}
Upland rice fields cover up to 1.8 million hectares of the 4.7 million hectares of global rice fields, while farmers' average yield of upland rice is far below the yield potential of existing traditional genotypes, particularly in West Africa. Grain yields of rice in Liberia are generally low, ranging from 0.5-1.5 tons per hectare $(\mathrm{t} / \mathrm{ha})$. A field study was conducted to evaluate yield and agronomic performances of four genotypes of rice (Nerica 8, Nerica 4, Arica 5 and LAC 23) on a typical fine sandy loam soil in the upper highland tropical forest agro-ecological Zone (UHTF AZ) of Liberia. The Randomized Complete Block Design (RCBD) was used with four replicates in four blocks. Data were taken on key agronomic characters including plant height; days to $50 \%$ flowering; number of tillers; number of panicles; grain weight; panicle length; number of grains per plant; seed length and stem diameter at the base. Results from the Analysis of Variance (ANOVA) indicated that there were significant differences between the control (Lac 23) and the improved genotypes (Nerica 8, Arica 5 and Nerica 4) for all characters measured except for panicle length, seed length and stem diameter. Correlation analysis was also performed to establish extent of association between major yield components and grain yield. Days to $50 \%$ flowering correlated significantly with plant height, number of tillers and number of panicles per plant. Nerica 8, Arica 5 and Nerica 4 recorded the highest yield and may, therefore, be recommended to smallholder farmers in the upper highland forest zone. Lac 23, Arica 5 and Nerica 8 may be recommended for local farmers, who prefer high yielding, and relatively medium heighted improved rice cultivars or their interspecific hybrids. This is because extremely tall rice genotypes are susceptible to lodging, particularly in stormy conditions that are prevalent in the upper highland tropical forest agro-ecological zone of Liberia. Other approaches may be required to test these cultivars under harsh environments (such as water deficit condition) and different agroecologies across the country. We also recommend organoleptic assessments of Nerica 4, Nerica 8 and Arica 5 to boost their acceptability among consumers in the country.
\end{abstract}

Key words: Upland rice, agronomic performance, improved genotypes, Nerica, correlation, Liberia 


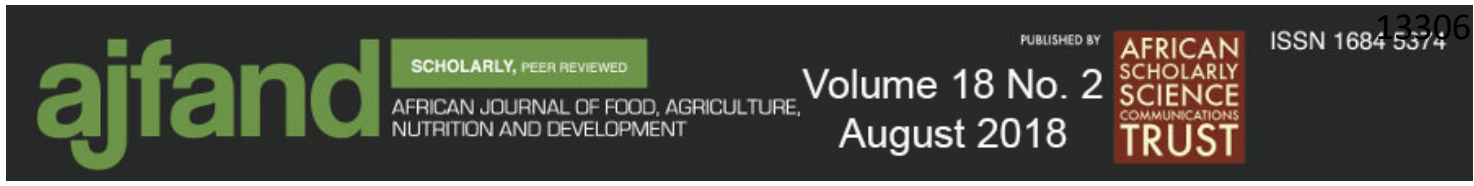

\section{INTRODUCTION}

Rice consumption in West Africa has more than doubled in the last decade due to population growth and changing consumer dietary preferences [1]. Adoption of agronomic practices is critical for increased yields as rice production has not kept pace with the level of consumption in the sub-region [2]. Upland rice fields constitute 1.8 million hectares of the 4.7 million hectares of rice fields while farmers' average yield of upland rice is far below the yield potential of existing genotypes globally [3].

Rice (Oryza spp L.) is the most important cereal crop grown in Liberia and is consumed by many Liberians [4]. However, rice production and productivity are low in the country. For instance, yields of upland rice ranged from 0.5-1.5 tons per hectare (t/ha) [5] despite the potential of 3.5-4.7 $\mathrm{t} / \mathrm{ha}[2,6,7]$. The low production and yields are due to a number of factors such as soils with poor organic matter and nutrients deficit, compounded by climate variability and limited availability of improved genotypes adaptable to the various agro-ecological zones across the country. Consequently, the demand for rice in Liberia has quadrupled and, thereby, far exceeds production levels. As a result, rice imports keep growing at a fast rate [2] as local rice production has been mainly under upland conditions and primitive agronomic practices, with farmers clearing new forest lands every year.

New Rice for Africa (NERICA), is a genetic material derived from the successful crossing of the two species of cultivated rice, the African rice (Oryza glaberrima Steud.) and the Asian rice (Oryza sativa L.), to produce a progeny that combines the best traits of both parents: high yields from the Asian parent and tolerance of the African parent to harsh environments [6]. This improved genotype (NERICA) is a new type of upland rice that perfectly adapts to the rain-fed upland ecology in sub-Saharan Africa (SSA), where smallholder farmers lack the means to irrigate and apply chemical fertilizers. However, NERICA genotypes also respond even better than traditional genotypes to higher inputs [5]. On the other hand, LAC 23 is the best upland local variety in Liberia, which was developed by IRRI scientists in the late 70 s through varietal selection at the Liberian Agriculture Company (LAC). The name of the variety was named after the selection site. It is adapted to multiple local agro-ecologies and is late maturing (140-150 days to maturity) $[5,8,9]$.

Nearly 70 percent of the economically active population of the 3.5 million Liberians depends on agriculture as a source of livelihood [6]. Rice is among major cereals cultivated by smallholder farmers. Rice trade for Liberia is projected to grow at $3.3 \%$ per annum, increasing in metric tons (MT) from 220 in 2011 to 313 by 2022 as consumption has been projected to increase by 3\% per year from 409 MT in 2011 to 567 MT by 2022 $[1,3,5]$. The domestic supply projection reflecting an annual growth of $2.7 \%$ is based on an expansion in area harvested of $1.7 \%$ per year and an increase in yields of only $1 \%$ per year [5]. As such, the dependency on imports remains approximately $60 \%$.

Farmers can adapt to climate change to some degree by varying planting dates, selecting genotypes with different growth duration, and/or adopting crop rotations. However, many of these coping mechanisms may result in lower yields as grain yield in rice is a complex quantitative trait that depends on a number of environmental and genetic factors 


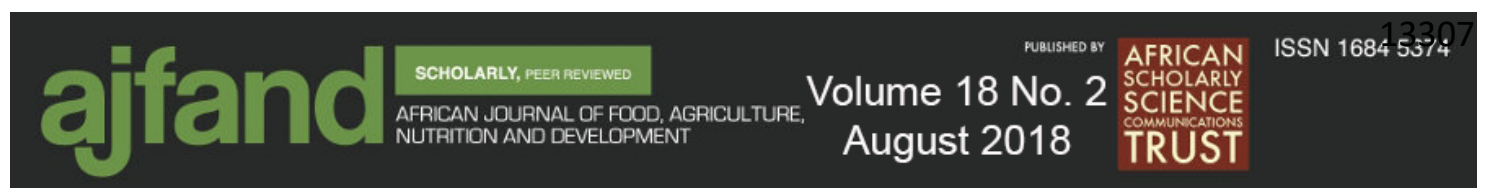

[7]. The direct and indirect effects contributed by each character towards yield will be an added advantage in aiding the selection process if information on character association is provided. Correlation analysis makes it possible to establish extent of association between yield and its components and also highlights relative importance of their direct and indirect outcome on grain yield [8].

The Government of Liberia through the Ministry of Agriculture is encouraging local farmers to engage in rice farming. Local farmers are, however, constrained by limited amount of agricultural inputs, predominantly improved and adapted genotypes to the local agroecology [9, 10]. The aim of this study was to evaluate the agronomic performance (plant height; number of days to $50 \%$ flowering; number of tillers per plant; number of panicles per plant; 1000 grain weight per plant, panicle length; seed length and stem diameter at the base) of three improved upland rice genotypes (Nerica 8, 4, Arica 5) and a landrace ( $\operatorname{Lac} 23)$ in a typical fine sandy loam soil in Suakoko.

\section{MATERIAL AND METHODS}

\section{Study site, experimental design and field layout}

The study was conducted at Suakoko in a typical tropical forest agro-ecology of Bong County, approximately 72 miles from Monrovia, the Nation's capital. The experimental field is located at latitude $07 \circ 41^{\prime} \mathrm{N}$ and longitude $9 \circ 55^{\prime} \mathrm{W}$ at an elevation of 76 metres above sea level within the upper highland tropical forest agro-ecological zone (Figure 1).

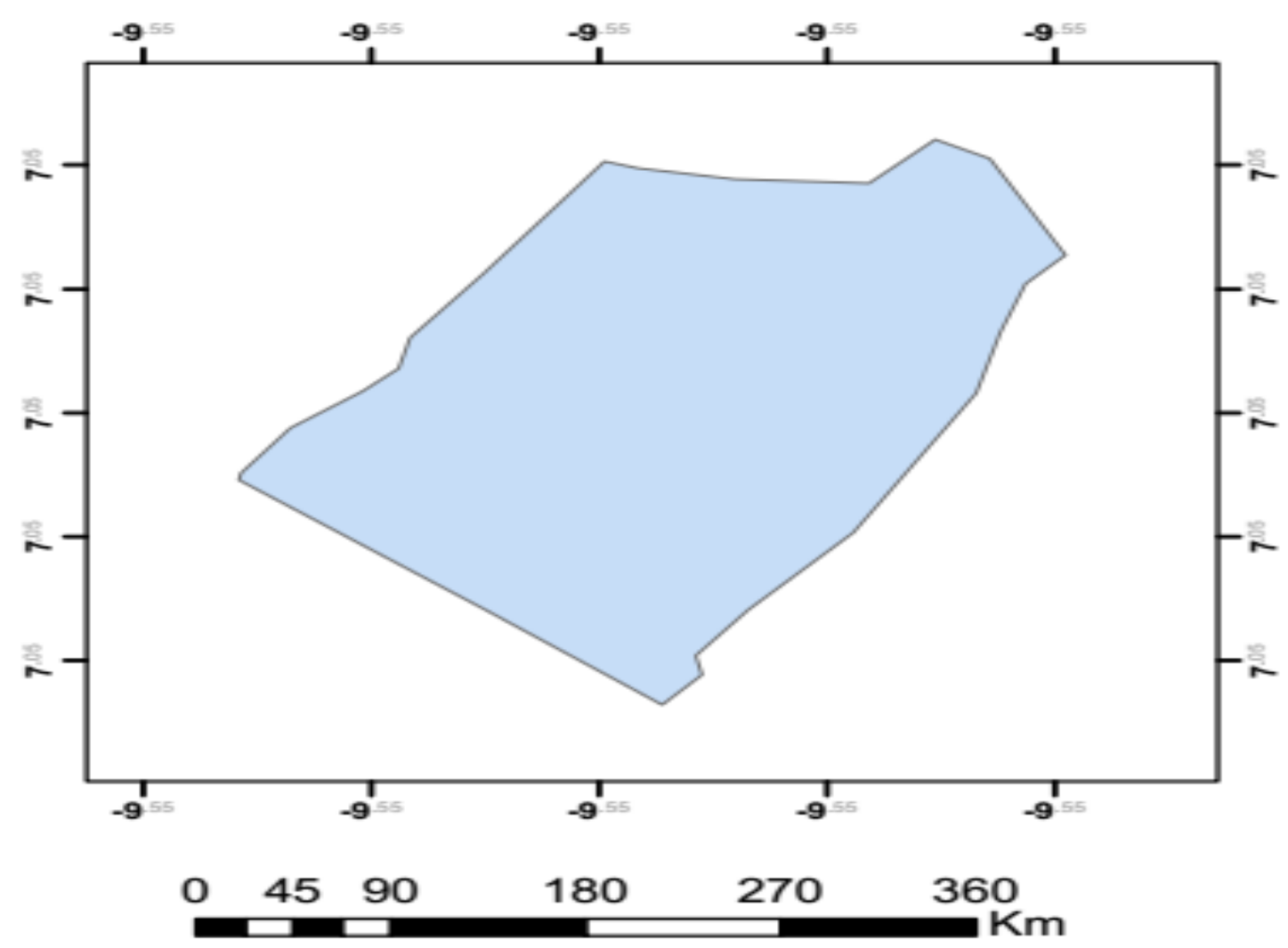

Figure 1: Map of the study location 


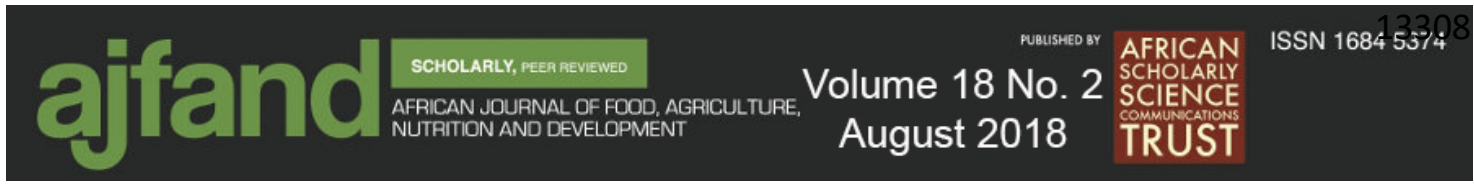

The soil at the study site is of fine sandy loam type. Rainfall and temperature for the study period ranged from 90.6-428.6 mm and $26-30^{\circ} \mathrm{C}$, respectively (Figure 2 and Table 1). The location previously had a 3 -season rice and peanut-corn intercrop for the past cropping seasons. The field was cleared and manually ploughed to provide a fine tilth for cultivation. Three improved rice genotypes (Nerica 4, Nerica 8, and Arica 5) and a local genotype (LAC 23 used as a check), were obtained from the Central Agriculture Research Institute (CARI) for the study. The experiment was laid out on 14 March, 2016 in a Randomized Complete Block Design (RCBD) with each genotype replicated four times in four blocks. Each plot was demarcated with a $40 \mathrm{~cm}$ walk way and a plot size of $2 \mathrm{~m} \times 2 \mathrm{~m}$. Prior to planting, chicken manure was applied at a rate of $1 \mathrm{~kg} / \mathrm{plot}$ to improve soil structure and nutrient content. At planting, three seeds were directly sown at a spacing of $20 \times 20 \mathrm{~cm}$ per hill but later thinned to two at emergence to obtain a total plant population of100 plants/plot. Planting was done on 26 May, 2016. Weeds were manually controlled (2 times) 20 days after sowing and at maximum tillering stage. A biopesticide, Neem extract $(100 \mathrm{ml})+$ Kerosene $(100 \mathrm{ml})+$ Carbolic soap $(100 \mathrm{~g})$ was formulated and applied 15 days after sowing to control pest and diseases. Also, Dursband was applied at $50 \mathrm{ml} / 16$ litres at panicle initiation stage to control stem borer infestation within the field. Soil samples were taken at a depth of $0-15 \mathrm{~cm}$ in each block at the time of rice planting. The samples were air-dried and sieved for soil analyses. Measurements were made of $\mathrm{pH}$ in a 1:1 ratio of soil/water and extractable $\mathrm{P}$ (Bray-2) (Table 1). At harvest, the middle portion of each plot $\left(1 \mathrm{~m}^{2}\right)$ was harvested and the grain weight (grain yield was reported at 14\% moisture) represent the plot after drying [11]. Ten selected rice hills were sampled from inside the harvested area for measurement of plant height, panicle number and length, number of tillers, stem diameter and dry weight of grains and averaged. Harvesting commenced at mid-September and proceeded to early November in 2016.

\section{Data Collection and Analyses}

Data were collected on days to $50 \%$ flowering $\left(\mathrm{FPF}_{1}\right)$; plant height $(\mathrm{PH})$; number of tillers per plant (\#tillers); number of panicle per plant (\#panicles); 1000 grain weight per plant (GW, 10 plants); seed length (SL) and stem diameter (SD). Except for days to flowering, all other data were collected at harvest. Harvesting was undertaken within 4 months after planting when $50 \%$ of the crop had reached physiological maturity; PH, SL and SD were measured in $\mathrm{cm}$ while $\mathrm{GW}$ was taken in $\mathrm{g}$ using an electronic scale. Plant height $(\mathrm{PH})$ was measured from the plant base to the topmost part with a tape measure. Stem diameter (SD) was measured using a pair of Vernier calipers while SL was measured using an electronic rule. Analysis of Variance (ANOVA) was performed to determine level of significance among the genotypes (LSD) $(\mathrm{P} \leq 0.05)$ using the Statistix Software Package (ver. 8.0). Pearson coefficients of correlation were calculated to determine degree of associations among these characters.

\section{RESULTS AND DISCUSSION}

The soil physico-chemical data indicate that for soil and climatic conditions of the study site, the genotypes may not adequately meet demand of storage sites for carbohydrates for photosynthetic activity due to the varying weather conditions (Table 1). The analysis of variance revealed that genotypes were differently impacted by the monthly rainfall 


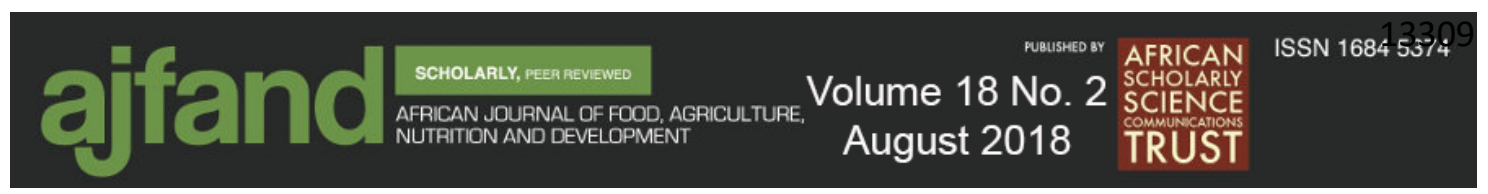

variations. This can be explained by the varying monthly climatic conditions [12], especially rainfall distribution that occurred during the periods of study (Figure 2, Tables 1 and 2).

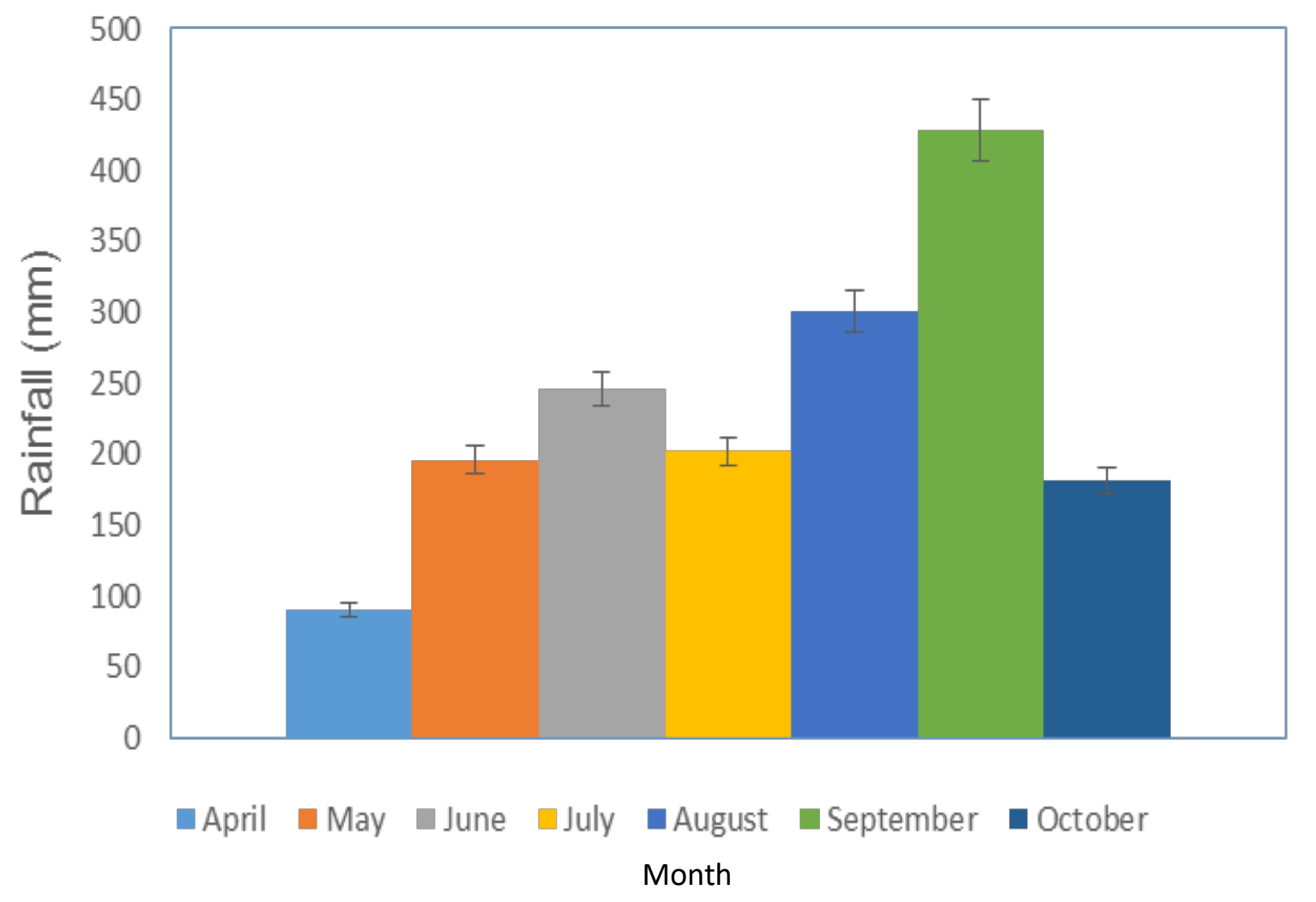

Figure 2: Rainfall Trend during the study period (error bars indicates standard
errors of deviations)

All four genotypes showed significant differences $(\mathrm{P} \leq 0.05)$ for $\mathrm{PH}, \mathrm{FPF}_{\mathrm{l}}, \mathrm{GW}$, \#Tillers and PL per plant (Table 2). Moreover, there were significant differences $(\mathrm{P} \leq 0.05)$ for number of grains per panicle and seed diameter for the three improved genotypes except for LAC 23 (Table 2). Nerica 8 registered the highest GW (1338.8 g) while Lac 23 recorded the least of $1082.5 \mathrm{~g}$. Significant differences in GW were recorded among the varieties. For instance, all improved varieties recorded higher $(\mathrm{P} \leq 0.05)$ grain weights than the local check. Similarly, although the grain weights of Nerica 8 and Arica 5 were not significantly different, each of them registered GW superior $(\mathrm{P} \leq 0.05)$ to that of Nerica 4 and Lac 23. This may be attributed to the lateness of LAC 23 in flowering and fruiting hence coincided with terminal drought (Table 1, Figure 2), causing less assimilate to be translocated for grain formation. Most of the grains for LAC 23 were not fully filled, resulting in lower weight of grains. This is consistent with a previous report [11] as the high temperature (Table 1) during the dry period may have induced flower sterility. Good performance of the three genotypes (Nerica 8, Arica 5 and Nerica 4) under nutrient-rich and rain-fed growing conditions has also been reported in the Philippines $[13,14,15]$. The high grain weight of Nerica 8 , Arica 5 and Nerica 4 in this study is inconsistent with Sürek et al. [16] and Babu et al. [15] in the Philippines, but is in consonance with report by Saito et al. [11], and George et al. [13] in Laos and Brazil. 


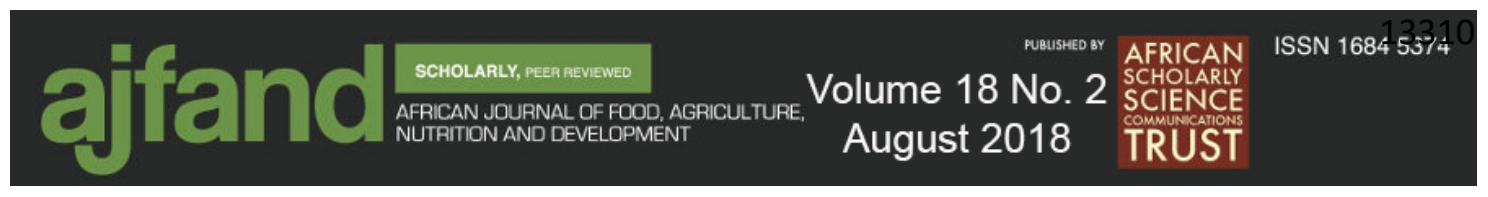

Nerica 8, Arica 5 and Nerica 4 recorded similar yield, possibly due to their hardiness and adaptation to harsher environments as they might have exploited their early maturity periods by amassing the greater share of photo-assimilates into grain production. This might have accounted for grains to be fully filled and, therefore, recorded heavier weights than Lac 23. Thus, our findings indicate that genotypes selected under favorable conditions (including moderate moisture and inputs) would perform well under most conditions in the tropical forest agro-ecological zone of Liberia $[11,13]$.

Additionally, there were significant differences among all the genotypes including the local genotype $(\mathrm{P} \leq 0.01)$ with respect to plant height. However, Nerica 8 registered the shortest plant height $(103.55 \mathrm{~cm})$ while Lac 23 recorded the tallest plant height of 131.35 $\mathrm{cm}$ (Table 2). Majority of rice farmers in Liberia prefer tall plants to lessen the burden of slouching to cut the panicles with a knife during harvesting. However, extremely tall rice cultivars have a propensity to lodge, particularly, under stormy conditions; hence high yielding, relatively medium height and improved rice cultivars or their interspecific hybrids are recommended [17]. Days to 50\% flowering as indicator of earliness for rice showed significant differences $(\mathrm{P} \leq 0.05)$ for all of the genotypes studied. Nerica 8 recorded the shortest maturity date $(\mathrm{n}=87)$ while LAC 23 recorded the longest maturity date of $n=139$ (Table 2).

There was no significant difference $(\mathrm{P} \leq 0.05)$ for number of tillers for both the local and improved genotypes studied. The number of panicles for all the genotypes studied was significantly different; while the panicle length for all the genotypes was not significantly different from each other $(\mathrm{P} \leq 0.05)$. Nerica 8 recorded the longest panicle length $(26.5$ $\mathrm{cm}$ ) and Arica 5 recorded the shortest panicle length of $23.5 \mathrm{~cm}$ (Table 2). The increase in some of these agronomic characters could be ascribed to the fact that plant height, and number of tillers affect panicle traits and those plants with moderate heights could utilize energy from the sun for improved photosynthesis [18]. Rice genotypes with such photosynthetic potential are noted for high yield as a result of effective utilization of sunlight for efficient photosynthetic process. Despite the observed variations in all these characters, all the genotypes had the normal range of values for all the traits studied in consonance with previous reports [19, 20], except for number of seeds per panicle and days to $50 \%$ flowering. Grain weight was significantly correlated $(\mathrm{P} \leq 0.05)$ with number of tillers, number of panicles and plant height (Table 3). Grain weight, stem diameter, and plant height significantly correlated with grain yield $(\mathrm{P} \leq 0.05)$. This compares well with reports by Matsui et al. [21], and Vange and Obi [22].

Number of tillers $(r=-0.828)$ and number panicles $(r=-0.947)$ correlated significantly and inversely with days to $50 \%$ flowering $(\mathrm{r}=-0.946)$. These correlation indices estimated are very good since leaf and panicle water potential are highly associated with panicle exertion and anther dehiscence [23]. The benefits of earlier flowering over later flowering in terms of higher spikelet fertility, higher harvest index, and higher grain yield have been variously proven and demonstrated by Lafitte et al. [24] and Guimarães et al. [25]. Conversely, 'genotypes with more tillers tend to have more roots, but shorter secondary and tertiary tillers, which may develop later. A deep root system with higher root density is useful under spasmodic drought if growing conditions permit root development at depth' [25]. 


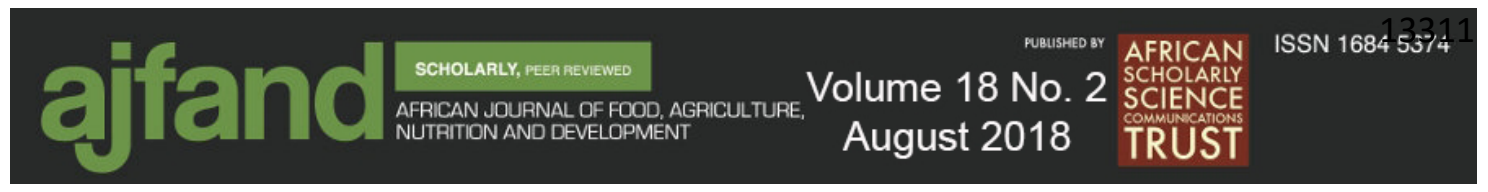

Plant height, however, recorded significant negative correlation with number of tillers ( $\mathrm{r}$ $=-0.914)$ and number of panicles per plant $(\mathrm{r}=-0.933)$. Guimarães et al. [25], Kamoshita et al. [26], and Kato et al. [27]; however, reported that rice genotypes with higher plant heights are usually larger in overall plant size, intercept more sunlight and use water faster through transpiration, leading to lower plant water status, higher dead leaf scores, and more spikelet sterility. It was observed that the most productive genotypes under the rain-fed conditions were those with the highest number of panicles and tillers per plant, and well-formed grains. This corroborates the report by Lafitte et al. [24].

The number of panicles had significant correlation with number of grains per plant, while pod length recorded significant positive and negative correlations with grain weight and seed length and stem diameter, respectively (Table 3). Seed length positively and negatively correlated with stem diameter and grain weight, respectively. Stem diameter recorded significant negative correlation $(\mathrm{r}=-0.819)$ with grain weight. Agronomic characters in rice have a certain degree of associations with each other and particularly traits such as plant height, tillering, panicles, and early maturation [17]. Most of these agronomic traits are controlled by multiple genes each of which is positively or negatively effective in the performance of the crop. Tillering is a key component in agronomic performance of rice as it correlates well with panicle number as well as the grains eight (yield) [18]. Prime characters for grain quality and improved rice cultivars are defined by grain length, plant height, flowering period, grain weight, number of panicles and tillers per plant as these characters account for the acceptability, marketability and commercial success of modern rice genotypes [20, 28]. Rice genotypes with enhanced tolerance to varying climate and superior yield potential under conducive environments are the best for increasing yield in less irrigated conditions [18]. The study was conducted between the two major seasons of the forest agro-ecology (MayNovember) with potential inter-seasonal influence on performance of the genotypes.

\section{CONCLUSION}

Nerica 4, Nerica 8 and Arica 5 recorded comparably significant grain weight than LAC 23 with poultry manure application. These improved rice genotypes were generally early yielding with moderate plant heights and resilient to variations in climate in the local agroecology. Nerica 8 was the most productive among the genotypes tested. Nerica 8 , Nerica 4 and Arica 5 had lower plant height, shorter flowering period, higher grain weight, more panicles and tillers per plant than the traditional cultivar (Lac 23). These traits are crucial for cultivars with enhanced yields. Other approaches may be required to test these cultivars under harsh environments (such as water deficit condition) and different agro-ecologies across the country. We also recommend organoleptic assessments of Nerica 4, Nerica 8 and Arica 5 to enhance prospects of consumer acceptance of these improved genotypes in the country. 


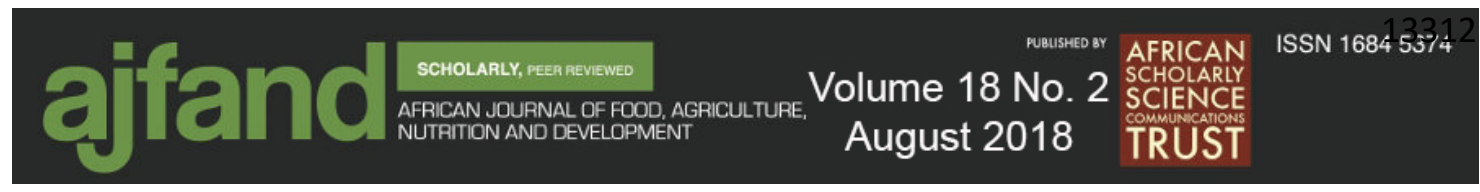

Table 1: Soil physico-chemical properties and weather information of the study site

\begin{tabular}{rcccccccccc}
\hline Parameter & $\begin{array}{c}\mathrm{K} \\
(\mathrm{kg} / \mathrm{ha})\end{array}$ & $\begin{array}{c}\mathrm{N} \\
(\mathrm{kg} / \mathrm{ha})\end{array}$ & $\begin{array}{c}\mathrm{P} \\
(\mathrm{kg} / \mathrm{ha})\end{array}$ & $\% \mathrm{OM}$ & $\mathrm{pH}$ & \%Clay & \%Sand & \%Silt & Rainfall $(\mathrm{mm})$ & $\begin{array}{c}\text { Temperature } \\
\left({ }^{\circ} \mathrm{C}\right)\end{array}$ \\
\hline Mean & 80.275 & 58.675 & 37.075 & 37.65 & 6.165 & 2.75 & 87.75 & 8.525 & $90.6-428.6$ & $26.05-30.5$ \\
\hline
\end{tabular}

Table 2: Agronomic performance of four upland rice genotypes under rain-fed condition

\begin{tabular}{lcccccccc}
\hline Genotype & $\begin{array}{c}\text { PH } \\
(\mathbf{c m})\end{array}$ & FPFl & \#Tillers & \#Panicle & GW (g) & $\begin{array}{c}\text { PL } \\
(\mathbf{c m})\end{array}$ & $\begin{array}{c}\text { SL } \\
(\mathbf{c m})\end{array}$ & $\begin{array}{r}\text { SD } \\
(\mathbf{c m})\end{array}$ \\
\hline Nerica 8 & $103.5^{\mathrm{d}}$ & $65.3^{\mathrm{d}}$ & $13^{\mathrm{a}}$ & $11^{\mathrm{a}}$ & $1338.8^{\mathrm{a}}$ & $26.5^{\mathrm{a}}$ & $8.6^{\mathrm{b}}$ & $2.2^{\mathrm{a}}$ \\
Nerica 4 & $107.4^{\mathrm{c}}$ & $71.8^{\mathrm{c}}$ & $11^{\mathrm{b}}$ & $9^{\mathrm{b}}$ & $1276^{\mathrm{b}}$ & $25.0^{\mathrm{ab}}$ & $9.0^{\mathrm{ab}}$ & $2.4^{\mathrm{a}}$ \\
Arica 5 & $116.8^{\mathrm{b}}$ & $73.5^{\mathrm{b}}$ & $10^{\mathrm{bc}}$ & $10^{\mathrm{a}}$ & $1333^{\mathrm{a}}$ & $23.5^{\mathrm{b}}$ & $9.3^{\mathrm{a}}$ & $2.6^{\mathrm{a}}$ \\
Lac 23 & $131.3^{\mathrm{a}}$ & $113.8^{\mathrm{a}}$ & $8^{\mathrm{c}}$ & $6^{\mathrm{c}}$ & $1082.5^{\mathrm{c}}$ & $25.3^{\mathrm{ab}}$ & $8.9^{\mathrm{b}}$ & $2.3^{\mathrm{a}}$ \\
\hline CV \% & 4.3 & 0.9 & 14.9 & 15.8 & 3.98 & 5.25 & 1.9 & 11.2 \\
SE & 2.47 & 0.36 & 0.78 & 0.72 & 24.73 & 0.65 & 0.08 & 0.13 \\
LoS & $* *$ & $* *$ & $*$ & $*$ & $*$ & $*$ & $*$ & $\mathrm{~ns}$ \\
\hline
\end{tabular}

Means with the same letters within the same column are not significantly different. LoS $=$ level of significance, $n s=$ not significant; $P H=$ Plant Height; $F P F l=$ days to $50 \%$ flowering; \# Tiller = Number of Tillers; \# Panicle $=$ Number of Panicle; GW $=$ Grain weight, $P L=$ Panicle length; $S L=$ Seed length and $S D=$ Stem diameter at the base 


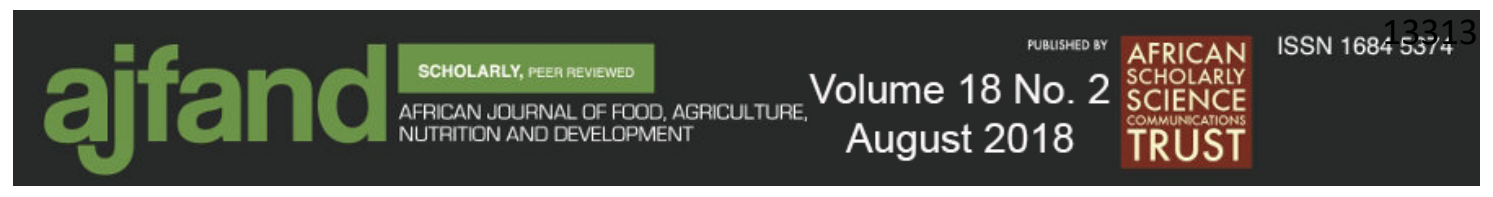

Table 3: Pearson correlation coefficients between quantitative traits of rice genotypes evaluated

\begin{tabular}{|c|c|c|c|c|c|c|c|c|c|}
\hline Trait & FPFl & $P H$ & Tiller & Panicle & $P L$ & $G P$ & $S L$ & $S D$ & $G W$ \\
\hline \multicolumn{10}{|l|}{ FPFI } \\
\hline PH & $0.949 * * *$ & & & & & & & & \\
\hline Tiller & $-0.828 * *$ & $-0.914 * * *$ & & & & & & & \\
\hline Panicle & $-0.946 * * *$ & $-0.933 * * *$ & $0.947 * * *$ & & & & & & \\
\hline PL & -0.056 & -0.340 & $0.577^{*}$ & 0.285 & & & & & \\
\hline GP & -0.370 & -0.427 & $0.750 * *$ & $0.651^{*}$ & $0.618^{*}$ & & & & \\
\hline SL & -0.260 & 0.040 & -0.283 & 0.039 & $-0.947 * * *$ & -0.426 & & & \\
\hline SD & -0.369 & -0.090 & -0.195 & 0.123 & $-0.906 * * *$ & -0.451 & $0.986 * * *$ & & \\
\hline GW & 0.031 & -0.287 & 0.368 & 0.076 & $0.889 * *$ & 0.202 & $-0.901 * * *$ & $-0.819 * * *$ & \\
\hline
\end{tabular}

$*=$ significant $(P \leq 0.05) ; * *=$ very significant $(P \leq 0.001) ; * * *=$ highly significant $(P$ $\leq 0.0001)$ computed using standard linear Pearson correlation. $P H=$ Plant Height; $\mathrm{FPFl}=$ Days to 50\% flowering; \# Tiller $=$ Number of Tillers; $\#$ Panicle $=$ Number of Panicle; $G W=$ Grain weight, $P L=$ Panicle length; $G P=$ Number of grains per plant; $S L=$ Seed length and $S D=$ Stem diameter at the base 


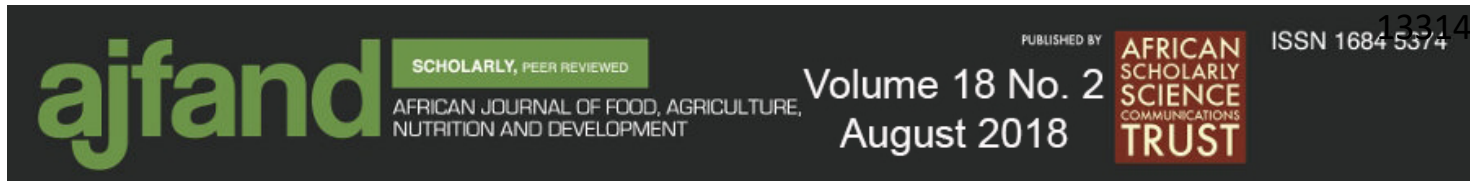

\section{REFERENCES}

1. PA, Tollens E, Woperei MC, Diagne A and I Bamba Rising trends and variability of rice prices: Threats and opportunities for sub-Saharan Africa. Food Policy. 2010; 403-411. http://dx.doi.org/10.1016/j.foodpol.2010.05.003.

2. Somado EA, Guei RG and SO Keya NERICA, 2008 edition ed., Cotonou: Africa Rice Center (WARDA), 2008.

3. Becker $M$ and DE Johnson Improved water control and crop management effects on lowland rice productivity in West Africa. Nutr. Cyc. Agro-Ecosyst. 2001; 59: 119-127. http://dx.doi.org/10.1023/A:1017585328904.

4. Manneh B Genetic, Physiological and Modelling Approaches towards Tolerance to Salinity and Low Nitrogen Supply in Rice, Wageningen: Wageningen University, 2004.

5. Ministry of Agriculture Quarterly Report Ministry of Agriculture, Government of Liberia, Monrovia: Government of Liberia, 2010: 21-35.

6. Pramod T, Abrol YP and $K$ Suman Collection and conservation of rice germplasm in India, I. K. International Group, 2009; 128.

7. Jun MA, Wen-Bo MA, Dong-Feng M, Shing-Ming $Y$ and $Z$ Qing-seng Characteristics of the rice plant with heavy panicle. Agr. Sci. Chin. 2007; 5(12): 911-918.

8. Amoatey HM, Sossah FL, Ahiakpa JK, Quartey EK, Appiah AS and MM Segbefia Phenotypic profiles of different accessions of sweet potato (Ipomoea batatas L. Lam) in the coastal savanna agro-ecological zone of Ghana. Afr. J. Agr. Res. 2016; 11(26): 2316-2328. http://dx.doi.org/10.5897/AJAR2016.11034.

9. Atlin GN and HR Lafitte Developing and testing rice varieties for water-saving systems in the tropics, in Water-Wise Rice Production. Proceedings of the International Workshop on Water Wise Rice Production, Los Banos, International Rice Research Institute (IRRI), 2002; 75-283.

10. Paterson AH, Freeling $M$ and T Sasaki Grains of knowledge: genomics of model cereals. Genom. Res. 2005; 15: 1643-1650. http://dx.doi.org/10.1101/gr.3725905.

11. Saito K, Linquist B, Atlin GN, Phanthaboon $K$, Shiraiwa $T$ and $T$ Horie Response of traditional and improved upland rice cultivars to $\mathrm{N}$ and $\mathrm{P}$ fertilizer in northern Laos, Field Crops Res. 2006; 96: 216-223. http://dx.doi:10.1016/j.fcr.2005.07.003.

12. Seyed MS Heritability, phenotypic correlation and path coefficient studies for some agronomic characters in landrace rice genotypes. World Appl. Sci. J. 2011; 13(5): 1229-1233. 


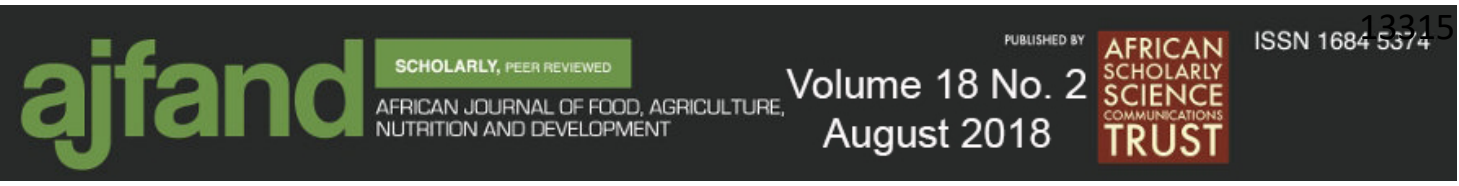

13. George $\mathbf{T}$, Magbanua $\mathbf{R}$, Roder $\mathbf{W}$ and $\mathbf{K}$ Van Keer Upland rice response to phosphorus fertilization in Asia, Agro J. 2001; 93: 1362-1370. http://dx.doi.org/10.4236/as.2014.56053.

14. George T, Magbanua R, Garrity DP, Tuban BS and J Quiton Rapid yield loss of rice cropped successively in aerobic soil, Agro J. 2002; 94: 981-989.

15. Babu VR, Shreya K, Dangi KS, Usharani G and $P$ Nagesh Genetic variability studies for qualitative and quantitative traits in popular rice (Oryza sativa L.) hybrids of India. Int. J. Sci. Res. 2012; 2(6): 1-5.

16. Sürek H, Korkut $\mathbf{Z K}$ and $O$ Bilgin Correlation and path analysis for yield and yield components in rice in an 8-parent half diallele set of crosses'. Oryza, 1998; 35 (1): 15-18.

17. Soares ER, Fernandes R, da Silva Londero L, dos Santos DL, Corrêa SS, Corrêa ES, dos Santos RC, Gomes AP, Gomes AP, Galon L, Pires FF and R da Silva Gonçalves Agronomic Performance of Cultivars of Upland Rice in the Southern of the Region of Rondônia, Brazil, Agr Sci. 2014; 5: 513-518.

18. Malik RK, Gupta RK, Singh CM, Yadav A, Brar SS, Thakur TC, Singh SS, Singh AK, Singh $\mathbf{R}$ and RK Sinha Accelerating the Adoption of Resource Conserving Technologies in Rice-Wheat Systems of the Indo-Gangetic Plains, Hisar: CCS Haryana Agricultural University, 2005.

19. Maclean JL, Dawe DC, Hardy B and GP Hettel Rice almanac, source book for the most important economic activity on earth, Third edition ed., Rome: CIAT, $2002 ; 79$.

20. Smith CW and RH Dilday Origin, history, technology, and production of rice, 1st ed., Hoboken, Ed., New Jersey: John Wiley \& Sons, 2003.

21. Matsui T, Omasa $\mathbf{K}$ and $\mathbf{T}$ Horie High Temperature at Flowering Inhibits Swelling of Pollen Grains, a Driving Force for Thecae Dehiscence in Rice (Oryza sativa L.), Plant Prod. Sci., 2000; 3(4): 430-434. http://dx.doi.org/10.1626/pps.3.430.

22. Vange $\mathbf{T}$ and I Obi Effect of planting date on some agronomic traits of wetland rice genotypes at Markurdi, Benue State (Nigeria). J. Sus. Dev. Agr \& Env. 2006; 2: $80-84$.

23. Babu RV, Shreya K, Dangi KS and US Shankar Correlation and path analysis studies in popular hybrid rice in India. Int. J. Sci. Res, 2012: 2-7.

24. Lafitte HR, Courtois $B$ and M Arraudeau Genetic improvement of rice in aerobic systems: progress from yield to genes, Field Crops Res. 2002; 75: 171191. 


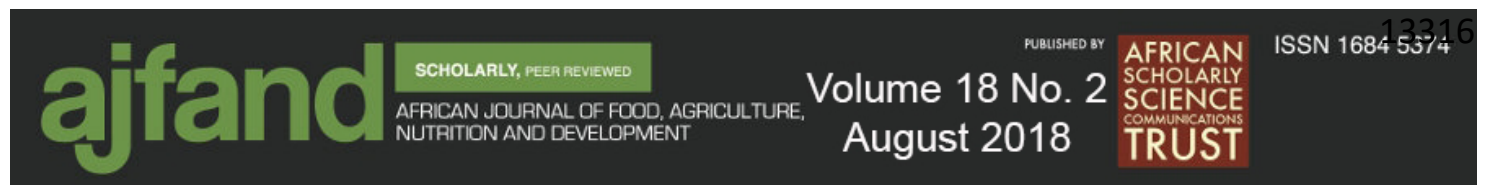

25. Guimarães CM, Stone LF, Rangel PHN and AC de L. Silva Tolerance of upland rice genotypes to water deficit', Revista Bras de Eng. Agr. Amb. 2013; 17 (8): 805810.

26. Kamoshita A, Rodriguez R, Yamauchi A and LJ Wade Genotypic variation in response of rainfed lowland rice to prolonged drought and dewatering. Plant Pro. Sci. 2004; 7: 406-420.

27. Kato $\mathbf{Y}$, Kamoshita $\mathbf{A}$ and $\mathbf{J}$ Yamagishi Evaluating the resistance of six rice cultivars to drought: root restriction and the use of raised beds. Plant \& Soil. 2007; 300:149-161.

28. Matlon $\mathbf{P}$, Randolph $\mathbf{T}$ and $\mathbf{R}$ Guei Impact of rice research in West Africa. In International Conference on the Impact of rice research, Bangkok, 1996:35-43. 